\title{
Squeezing Italian dictionaries in search of citrus juice and fruit
}

1 Introduction

2 Squeezing historical dictionaries

3 Squeezing contemporary dictionaries

4 Squeezing bilingual dictionaries
5 Squeezing other reference sources

6 Conclusions

7 Bibliography

7.1 Research literature

7.2 Dictionaries

\begin{abstract}
Southern Mediterranean regions significantly differ from the northern countries not only for their climate, but also and foremost for the influence that the latter has on the landscape and the products that are related to it. Dictionaries should relate the lexical variation used to describe the variety of landscapes and their characteristics, thus reflecting the peculiarities of a given territory.

This paper deals with the variety of citrus fruits that can be found in the Italian landscapes, with particular attention to the lexicographic treatment that they receive in both monolingual and bilingual dictionaries, where a precise meaning is not always registered and the treatment of the superordinate agrume (pl. agrumi) is controversial: its taxonomic status seems not to be recognized and fully exploited in dictionary articles.
\end{abstract}

Keywords: agrume, citrus, fruit, trees, rutaceae, dictionary, LandLex

Schlagwörter: Zitruspflanzen, Zitrusgewächs, Obst, Bäume, Rautengewächse, Wörterbuch, LandLex

\section{Introduction}

As Barbera/Biasi (2013) point out, citrus fruits (agrumi) have certainly inspired more still lives and botanical tables than landscape paintings. The term agrumi is unusually ambiguous in arboriculture, as it identifies both the fruits and trees that produce them. Nonetheless, a careful reading of the Italian landscape, as an emblematic expression of the Mediterranean one, gives citrus orchards a position of centrality in

Article note: This contribution is the result of a close collaboration between the two authors, nonetheless Elisa Corino wrote $\S \S 3,4,5$, Carla Marello wrote $\S \S ~ 2,6$.

Elisa Corino and Carla Marello, Università di Torino, Dipartimento de Lingue e Letterature straniere e culture moderne, Via Verdi, fronte 41, 10124 Torino, Italia, e-mail: elisa.corino@unito.it, carla.marello@unito.it 
the definition of its identity, not so much for its diffusion but rather for the multiplicity of forms with which they are actually cultivated.

The productive Italian citrus landscape is in fact recent, starting from the end of the $18^{\text {th }}$ century thanks to the affirmation of the high commercial value of the fruits, with their different uses, and in the wake of an early globalization of this market sector. At the beginning of the $20^{\text {th }}$ century, Sicilian lemons reached the markets of the United States every year, and the bergamot plants from Calabria for the production of essential oil had no rivals until the 1950s, not to mention the birth of the Chinotto drink formula obtained in 1949 from the fruits of Citrus myrtifolia, whose ambition was to represent the alternative to globalized drinks.

The Italian language uses the generic term agrume (pl. agrumi) to refer to all the known and widespread species and cultivars (oranges, mandarins, grapefruits, pummeli, lemons, limes, and cedars) which belong to the Citrus genus.

As Nicolosi (2013) reports, the term derives from the Latin form cedrus, which in turn derives from the Greek word $\kappa \varepsilon ́ \delta \rho \varsigma$, , which indicated cedar, pine, and cypress trees. The Citrus genus belongs to the order of the Geraniales, family Rutaceae, subfamily of the Aurantioideae. The Rutaceae family includes about 160 genera and as many as 1650 species of trees and shrubs. The identification of the area of origin and diffusion of citrus fruits represented a difficult reading that led to conclusions that were not always consistent. However today, on the basis of the research carried out, scholars agree in considering the tropical and subtropical regions of Southeast Asia, north-eastern India, southern China, the Indochinese peninsula and of the Malay archipelago the primary centers of origin from which citrus fruits began spreading to other continents.

The coexistence of two different etymologies which overlap and generate some kind of suppletion phenomena in Italian is pretty clear: on the one hand the word agrume, producing a series of derivative nouns and compounds, on the other hand the botanical term of Latin/Greek origin citrus, mostly used to create adjectives.

The aim of this paper is to show how the superordinate term agrume is used in the lexicographical landscape, pointing out the inconsistencies in the wordlist choices and article organization of the hyponyms by different dictionaries - both historical and contemporary - with a glimpse to the bilingual lexicography.

\section{Squeezing historical dictionaries}

The primitive meaning of agrume as 'disagreeable taste' dates back to the Medieval Latin àcrùmen -inis (from àcer) 'sour', as used by Dante in a figurative sense - Par., 17-117: "Ho io appreso quel che s'io ridico, / a molti fia sapor di forte agrume"1 - and

1 'things have I heard which, if repeated, will for many have the taste of bitter herbs' (transl. by C. Langdon. London: Cambridge Harvard University Press, 1921). 
it has no connection to the Citrus genus trees and fruits, which was first documented in 1556 by Gianvettorio Soderini in his Trattato della cultura degli orti e dei Giardini. ${ }^{2}$

The term was thus added to the taxonomy of the rutaceae family rather late and it was the result of a resemantization of the word, just as happened with citrus itself. As assumed by Villalva (2018), the trees that the Romans knew as citrus were cedars, coniferous trees in the pinaceae family, and the term was later adopted to refer to another set of trees. This led to a terminological confusion that still exists in Italian, as cedro might refer to both cedar and citrus.

As for agrume, the shift from the "old" to the "new" meaning was first registered by the second edition of the Vocabolario della Crusca (1623). Figure 1 clearly shows the increase of occurrences from the second edition on, suggesting a broadening of the scope of the meanings of the word and its uses.

La Ricerca di + agrum $^{*}$ : è stata estesa ad 6 Forme. Tempo Totale di Ricerca in 0 msec.

La ricerca è stata rilevata in 6 forme, per un totale di 121 occorrenze

\begin{tabular}{|c|c|c|c|c|c|}
\hline $1^{\circ}$ Edizione & $2^{\circ}$ Edizione & $3^{\circ}$ Edizione & $4^{\circ}$ Edizione & $5^{\circ}$ Ediz. & \multicolumn{2}{l|}{ totali } \\
\hline Diz. & Diz. & Diz. & Diz. & Lemm. & forme \\
\hline 5 & 6 & 6 & 3 & 1 & 6 \\
\hline 19 & 25 & 37 & 39 & 1 & 121 occorrenze \\
\hline
\end{tabular}

Figure 1: Distribution of agrum ${ }^{\star}$ in the Vocabolario della Crusca

If we go into more detail (as in Figure 2), tracing the occurrences for each edition, we can describe the change in meaning. ${ }^{3}$

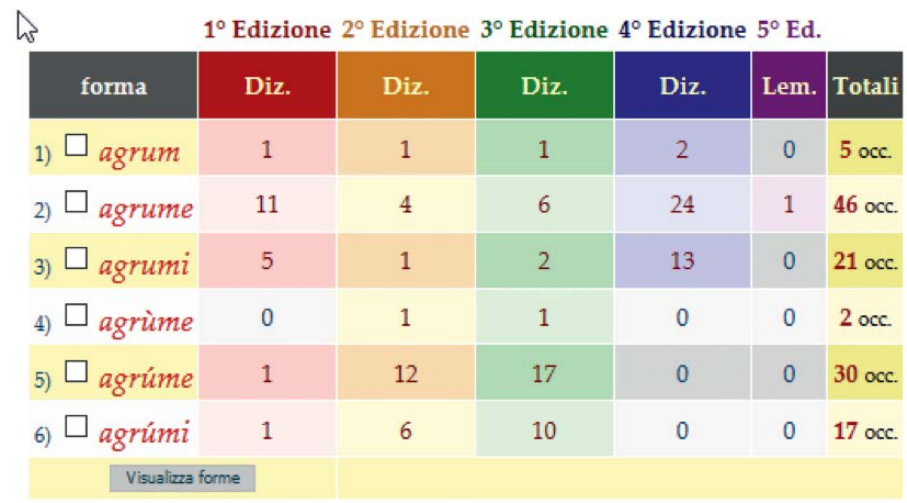

Figure 2: Details of the results for agrum ${ }^{\star}$ in the Vocabolario della Crusca

2 As quoted in the historical dictionary GDLI and reported in GDU.

3 The first result - agrum - is not to be considered, as it is the Latin accusative of ager, field. 
Agrume/ $i$ in the first edition is used to describe entries like garlic, onion, leek, and scallion and is linked to the adjective forte (stark) and the noun sapore (taste) - Dan. Par. 17. A molti fia savor di forte agrume.

The second edition introduces limone (lemon), melarancia (malum auream, which will later become arancia - orange), and cedro/cederno (citrus) in the definition (1). The adverb oggi (today) proves the shift in meaning, or at least the added value to the term, highlighting the difference from the past.

(1) AGRUME Definiz. Oggi diciamo anche agrúme a limoni, melarance, cederni, e altri frutti di questa spezie col sugo di sapore agro.

Lemon (2) and melarancia (3) are listed in the second edition dictionary as alone standing entries to be define as part of the agrume species.

(2) LIMONE

Definiz. Spezie d'agrúme molto simile al cedro, ma di sugo, e di buccia piu dolce, e piu amabile: chiamasi così l'albero, come il frutto, e ne son di diverse sorte.

(3) MELARANCIA Definiz. Frutta di figura simile alla mela, e di color rancio: spezie d’agrúme. Lat. malum aureum

The third edition (1691) adds melangolo (later sour orange), cedrato and cetrangolo (citruses of sorts), whereas in the fourth bergamotta (bergamot) appears in the word list (4) with both its meanings of pear and pear-shaped agrume.

(4) BERGAMOTTA Definiz. Sorta di pera morbida, e sugosa, che si matura del mese d'Ottobre.

[...]

Definiz. §. Si dice ancora d'una sorta d'agrume odorosissimo della stessa figura.

The resemantization is confirmed by the Tommaseo Bellini, where it is openly stated that the meaning of agrume as "genus of certain vegetables of strong and sharp taste, as of onions, garlics, leeks, etc." coexists with the reference to the citrus genus until the second half of the $18^{\text {th }}$ century. It is only in the $19^{\text {th }}$ century that agrume as "genus of lemons, melarance, and other similar fruits" asserts itself, up until present days when it has become the usual meaning, if not the only one known by most of the speakers. 
Tommaseo Bellini

\section{AGRUME.}

S. m. Da AGRO. [Bor.] Dicevasi propriamente pel genere di certi ortaggi di sapor forte ed acuto, come di cipolle, agli, porri, ecc. Ora dicesi il più spesso del genere de' limoni, delle melarance, e di altri somiglianti frutti. $=$ Pass. 36. (C) Dicono i savii che porri, cipolle e agli, e ogni agrume crudo, le fave, e ogni legume fanno avere $i$ sogni terribili e noiosi. M. Aldobr. Primieramente sieno guardati da tutti $i$ salsumi e agrumi, e principalmente... [Val.] Ant. Pucc. Capit. Moral. 4. 281. A noja m'è (chi vuole udir, sel oda) Chi mangia agrume, e poi tra le persone Senza riguardo a ragionare approda. Rucell. Ap. 623. Ma non voglio sentir fiato, che spiri D'impudico vapor, nè d'odor tetro, D'agli, porri, scalogni, o d'altro agrume. T. Cocch. Disc. 2. 130. Han ragione i Pittagorici di stimare molto l'aceto e tutti li sughi freschi acetosi degli agrumi e d'altri frutti, e dell'erbe.

2. Oggi diciamo Agrume a' Limoni, Melaranci, Cedri, e altri frutti di questa spezie. Cas. Galat. 21. (C) Come gli agrumi che altri mangia, te veggente, allegano i denti anco a te; così il vedere che altri si cruccia, turba noi. Sagg. Nat. esp. 231. Quei che lo fanno, sono universalmente tutte le acque naturali e stillate,... tutti i liquori acidi, e i sughi di tutti gli agrumi.

3. Trasl. Cosa noiosa, Rincrescevole, Fastidiosa. D. 1. 17. (M.) Ho io appreso quel, che s'io ridico, A molti fia savor di forte agrume. Pulc. Morg. 12. 12. (C) Cacciatel via, e' debb'essere un pazzo: Dond'è uscito questo strano agrume? Cas. Galat. 65. Anzi è l'agrume l'aloe della loro rustica natura ed aspera.

\section{AGRUME.}

S. m. from AGRO [sour]. [Bor.] It was properly referred to the genus of certain vegetables of strong and acute flavor, such as onions, garlic, leeks, etc. Now it refers most often to the genus of lemons, melarance, and other similar fruits. [...]

2. Today we say Agrume to 'Lemons, Melaranci, Cedars, and other fruits of this species. [...]'

3. Trasl. Boring, regrettable, annoying thing. [...]

The entry in the Tommaseo Bellini is noteworthy for both its modern structure and depth of analysis. The opposition between Dicevasi (it was referred to) and Ora dicesi più spesso (now it often refers to) for the genus reflects a survey of the uses and distribution of the meaning in the actual language. As for the morphosyntactic structure, the second meaning highlights the use of the term in its singular form (oggi diciamo agrume), and the third meaning adds the figurative sense to complete the article.

Whereas the Tommaseo Bellini organizes the term as just one entry with different meaning, the historical dictionary GDLI splits it into two separate, though homonymic, entries: agrume 1, for the old meaning referring to vegetables, and agrume 2 for the Citrus genus. This distinction might be the evidence of how differently the two meanings are perceived and how loose the relationship between them has become today, despite their common etymology. 
GDLI

Agrume1 sm. Sapore agro; acre, sgradevole anche al figur. [...]

2. Figur. Persona fastidiosa, irritante. [...]

3. Cibi di sapore agro, forte; ortaggio di sapore e odore acre e forte (come agli, cipolle, porri, peperoni, ecc.).

Agrume $2 \mathrm{sm}$. Bot. Nome delle specie coltivate (limone, arancio, arancio amaro, mandarino, bergamotto, cedro, chinotto, pompelmo, limetta) del genere citrus, della famiglia Rutacee: alberi o arbusti sempre verdi, alti da 1,50 a $15 \mathrm{~m},[\ldots]$

2. Frutto degli agrumi (di sapore più o meno agro).

Agrume1 Sour taste; acrid, unpleasant also figur. [...]

2. Figur. Annoying, irritating person. [...]

3. Foods with a sour, strong flavor; vegetable with a strong and acrid taste and smell (such as garlic, onions, leeks, peppers, etc.).

Agrume $2 \mathrm{sm}$. Bot. Name of the cultivated species (lemon, orange, bitter orange, mandarin, bergamot, cedar, chinotto, grapefruit, lime) of the genus citrus, of the Rutaceae family: ever green trees or shrubs, from 1.50 to $15 \mathrm{~m}$ high, [...]

2. Citrus fruit (more or less sour taste).

An interesting lexicographic treatment is to be noticed in a modern dictionary - De Mauro's GDU - which, being published in the $20^{\text {th }}$ and $21^{\text {st }}$ centuries, displays a distribution of meanings as follows: the first numbered meaning refers both to the Citrus genus, mentioning the tree characteristics first and - in a separate section not numbered - to the fruit. Examples are provided only for the fruit meaning; the second meaning with label LE (letterario 'word in literary texts') is the quotation from Dante; the third numbered section mentions the OB obsolete meaning "vegetable with a sour taste and strong smell”.

GDU

Agrume /a'grume/ s.m. CO

[av. 1321 nell'accez. 2. Dal lat. Mediev. acrūmen, der. di acer, acris “2agro"]

1 [av. 1556] spec. al pl., arbusto o albero sempreverde del genere Cedro, con fiori bianchi e frutti generalmente commestibili: coltivazione di agrumi | diviso in spicchi e dal sapore acidulo, come ad esempio l'arancia, il mandarino, il limone o il bergamotto: importazione di agrumi, spremuta di agrumi 2 LE sapore aspro, acre, sgradevole: a molti fia sapor di forte agrume (Dante)

3 OB cibo o ortaggio di sapore aspro e odore forte

DERIVATI agrumario, agrumeto

COMPOSTI agrumicolo, agrumicoltore, agrumicoltura, spremiagrumi 
Agrume /a'grume/ s.m. CO

$[\ldots]$

1 [av. 1556] spec. al pl., evergreen shrub or tree of the genus Cedar, with white flowers and generally edible fruits: citrus cultivation | divided into wedges and with a sour taste, such as orange, mandarin, lemon or bergamot: import of citrus fruits, citrus juice

2 LE sour, sour, unpleasant taste [...]

3 OB food or vegetable with a sour taste and strong smell

DERIVATIVES citrus, citrus grove

COMPOUNDS citrus, citrus grower, citrus growing, juicer

Since it is a Grande Dizionario dell'Uso (of Usage), a hint of use and distribution of the word is given through the label CO (COmmon) in the first line, and the history of the word is indirectly given through the date of the first documented mention "Av. 1321 nell'accez. 2" (before 1321 in the second meaning).

Comparing GDU and Tommaseo Bellini, the modernity and clearness of the latter is evident: even considering that 1321 was the year of Dante's death and going straight to 2 LE agro, the shift in meaning "before X/after X" is not clear at all and the reader has to infer it from the few unclear clues given in the article.

The $20^{\text {th }}$ and $21^{\text {st }}$-century one-volume dictionaries focus on the modern meaning giving the more ancient meaning as the last one and quoting Dante. Among the Italian monolingual dictionaries freely available on line only Treccani maintains the ancient meaning in the first place specifying ant. 'ancient'; Garzanti, Sabatini-Coletti, Grande Dizionario Hoepli Italiano di Aldo Gabrielli, all of them start from the modern meaning. ${ }^{4}$

\section{Squeezing contemporary dictionaries}

Contemporary dictionaries offer a wide variety of articles and are organized differently in both the article structure and the reference to agrume/i in the entries connected to the term, which are its actual hyponyms.

The first thing to notice is the difference between the GDU and Il Nuovo De Mauro, appeared 15 years after the GDU, as there is a sort of "regression" in the usage label of agrume: the former tags agrume as $\mathrm{CO}$, referring to it as to a common name usually known to anyone with a higher level of education, whereas for the latter it is in the $\mathrm{AD}$ (Alta Disponibilità - high accessibility) group, ${ }^{5}$ thus a noun relatively rare in speaking or writing, but all well-known because it is linked to acts and objects of

4 Also Zingarelli and Devoto Oli, accessible behind paywalls, give as first meaning the modern one; see next paragraph $\S 3$.

5 The Nuovo De Mauro AD word list (approximately 2500 words) was obtained from the old 230-word list of the previous edition by submitting it to groups of university students in order to delete those 
great importance in everyday life and therefore part of the Vocabolario di Base (Basic Vocabulary).

The definition and the article structure is the very same in both dictionaries (cfr. supra and infra).

II Nuovo De Mauro

a|grù|me

s.m.

av. 1321 nell'accez. 2; dal lat. mediev. acrūmen, der. di acer, acris "agro".

$A D$

1. CO spec. al plur., arbusto o albero sempreverde del genere Cedro, con fiori bianchi e frutti generalmente commestibili: coltivazione di agrumi | diviso in spicchi e dal sapore acidulo, come ad esempio l'arancia, il mandarino, il limone o il bergamotto: importazione di agrumi, spremuta di agrumi

2. LE sapore aspro, acre, sgradevole: a molti fia sapor di forte agrume (Dante)

3. OB cibo o ortaggio di sapore aspro e odore forte

\section{a|grù|me}

[...]

1. CO spec. al plur., evergreen shrub or tree of the genus Cedar, with white flowers and generally edible fruits: citrus cultivation | divided into wedges and with a sour taste, such as orange, mandarin, lemon or bergamot: import of citrus fruits, citrus juice

2. LE sour, sour, unpleasant taste [...]

3. OB food or vegetable with a sour taste and strong smell

The hyperonymic nature of the term is proved by the contexts in which it is mentioned in the WiV, Blumenthal Rovere (2018) where occurrences extracted from newspapers are given as examples and agrumi appears related to verbs such as danneggiare (il raccolto di agrumi) or elevare (i prezzi degli agrumi). The term is thus considered as a general category to encompass different species and cultivars.

It is to be expected, then, that dictionaries report this relation in the definitions of fruits and trees belonging to the category. A survey among some of the most important dictionaries used in Italy these days, though, proves the opposite.

First of all, the definitions are heterogeneous, giving different insights into the historical development of the word (or no information at all).

The Zingarelli, for instance and contrary to the De Mauro's, does not mention the shift from vegetables to fruits, nor does the Sabatini Coletti, as they both refer to only the sour taste as the ancient (or obsolete) meaning of the word.

words which were not perceived as AU (Alto Uso - high usage) any more, and to include new words which were perceived as AD instead. 
agrùme / a'grume/

[...]

1 (especially pl.) Usually, Rutaceae tree or shrub of the Citrus genus, evergreen, with white and fragrant flowers and juicy fruits, cultivated for the production of fruits and essences | the fruit of this plant, such as orange, lemon and sim.

$2+$ sour taste (also fig.) [...]

Zingarelli

agrùme / a a'grume/

[lat. parl. *acrūme(n), da ācrus. V. agro (1) 1320]

s. m.

1 (spec. al pl.) correntemente, albero o arbusto delle Rutacee del genere Citrus, sempreverde, con fiori bianchi e profumati e frutti succosi, coltivato per la produzione dei frutti e delle essenze | il frutto di tale pianta, quale arancia, limone e sim.

2 tsapore agro (anche fig.): io ti disfido a morte / e farotti assaggiar d'un altro agrume (L. Pulci)

\section{agrume}

$[\ldots]$

1 (especially Pl.) Denomination of evergreen trees or shrubs with berry fruits, pulpy and juicy, with an acid or acid taste, rich in vitamins and essential oils; also, the fruit of such plants (lemon, orange, mandarin, cedar, grapefruit, bergamot etc.)

2 ant. Sour taste

- sec. XIV

Sabatini Coletti

agrume

[a-grù-me] s.m.

1 (spec. pl.) Denominazione di alberi o arbusti sempreverdi dai frutti a bacca, polposi e succosi, di sapore acido o acidulo, ricchi di vitamine e di oli essenziali; anche, il frutto di tali piante (limone, arancia, mandarino, cedro, pompelmo, bergamotto ecc.)

2 ant. Sapore agro

sec. XIV

The examples of agrumi given by the Zingarelli are limited to oranges and lemons (and the like, it says), De Mauro expands the list to tangerines and bergamot, Sabatini Coletti also mentions cedar and grapefruit.

The second remark concerns the list of entry words where agrume/i should be mentioned in the article as part of the taxonomical definition. The query of the whole dictionary to find out the lemmata where the term is present gives different result according to different dictionaries and gives a close insight on the landscape that the Italian lexicography actually describes, displaying different choices in the sorts of agrumi that are included in their lists. 
The following table shows the results of the search for agrum $^{\star}$ in three representative Italian dictionaries: the GDU, the Treccani, the Zingarelli. ${ }^{6}$

The table reports all the lemmata where agrum $^{\star}$ was used in the dictionary definition; were lemma is used, it means that the term is present in the dictionary as an entry, but it is not described as an agrume in the article.

Table 1: Agrum $^{\star}$, full text comparison

\begin{tabular}{lll}
\hline GDU & ZINGARELL & TRECCANI \\
\hline Agrocotto & Agrocotto & Agrocotto \\
Agrumario & Agrumario & Agrumario \\
-- & Agrumato & - \\
Agrume & Agrume & Agrume \\
Agrumeto & Agrumeto & - \\
Agrumicolo & Agrumicolo & Agrumicolo \\
Agrumicoltore & Agrumicoltore & Agrumicoltore \\
Agrumicoltura & Agrumicoltura & Agrumicoltura \\
Cedraia & Cedraia & Cedraia \\
$\checkmark$ Lemma & $\checkmark$ lemma & Cedrato \\
$\checkmark$ lemma & $\checkmark$ lemma & Cedrino \\
Cedro & $\checkmark$ lemma & Cedro \\
Chinotto & $\checkmark$ lemma & Chinotto \\
Egle & & Egle \\
Eremocedro & -- \\
Feronia & -- & Feronia \\
& - frutta & \\
$\checkmark$ lemma & $\checkmark$ lemma & Kumquat \\
$\checkmark$ lemma & $\checkmark$ lemma & Lima \\
$\checkmark$ lemma & $\checkmark$ lemma & Lime \\
$\checkmark$ lemma & $\checkmark$ lemma & Limetta \\
$\checkmark$ lemma & $\checkmark$ lemma & Limone \\
$\checkmark$ lemma & $\checkmark$ lemma & Limoncello \\
Mandarancio & $\checkmark$ lemma & $\checkmark$ lemma \\
$\checkmark$ lemma & $\checkmark$ lemma & Mapo \\
$\checkmark$ lemma & $\checkmark$ lemma & Pomelo \\
$\checkmark$ lemma & -- & Pomo \\
Pompelmo & $\checkmark$ lemma & $\checkmark$ lemma \\
$\checkmark$ lemma & -- Poncino \\
Ponciro & $\checkmark$ lemma & -- \\
\hline & & \\
\hline & & \\
\hline & & \\
\hline
\end{tabular}

6 Only the entries referring to agrume as fruit/tree will be taken into account. In particular we concentrate on the derivatives and the possible hyponyms referring to the fruits and trees of the genus and family, excluding entries for parts of the fruit, and different citrus fruit parasites.

Please note that the Treccani on line dos not allow the full text dictionary search, so the query was run first with agrume and then with agrumi. 
Tab. 1 (continued)

\begin{tabular}{lll}
\hline GDU & ZINGARELLI & TRECCANI \\
\hline Spremiagrumi & Spremiagrumi & Spremiagrumi \\
Tangelo & $\checkmark$ lemma & Tangelo \\
Ugli & -- & Ugly \\
\hline
\end{tabular}

If one expects to find out what kinds of agrumi - which as previously mentioned is a term belonging to the Italian basic vocabulary - are listed in the Italian dictionaries, the search in the whole dictionary is not always successful, depending on the dictionary and its approach in defining the terms.

The word lists resulting from GDU and Treccani - which are more than one-volume dictionaries - are undoubtedly wider than the one from Zanichelli, covering most of the fruits that would generally be mentioned by an average Italian speaker, and some more.

The main reason is to be found in the article structure: GDU first defines the terms tracing their relationship back to the common name agrume, then recalls the botanical taxonomy, whilst Zingarelli prefers to quote only the botanical family name rutaceae, which is scientifically thorough but less open to common mother tongue users and possibly foreign learners. Treccani is in between and sometimes inverts the order chosen by GDU, but does not renounce to mention the common name.

Zingarelli

chinòtto / « ki'notto/

[da China, antico n. della Cina 1892]

s. $\mathrm{m}$.

1 piccolo albero delle Rutacee con piccoli fiori bianchi molto profumati e frutti amari più piccoli dell'arancia (Citrus bigaradia sinensis) | il frutto di tale albero

2 bibita analcolica gassata, aromatizzata con estratto a base di chinotto

\section{chinòtto / ki'notto/}

[...]

1 small Rutaceae tree with small white flowers very fragrant and bitter fruits smaller than orange (Citrus bigaradia sinensis) | the fruit of that tree

2 carbonated soft drink, flavored with chinotto extract 
GDU

chinotto / ki'notto/ (chi-not·to) s.m. CO

[1892; der. di China, v. anche ${ }^{3}$ china, con-otto]

1a frutto giallo con polpa amara, utilizzato per sciroppi, marmellate e sim.

1b TS bot. com. agrume cespuglioso delle Rutacee (Citrus aurantium) con foglie ellittiche e fiori bianchi che produce tale frutto

2 CO bibita analcolica gassata, amarognola, aromatizzata con estratti di tale agrume

chinotto / ki'notto/ (chi·not·to) s.m. CO

[...]

1a yellow fruit with bitter pulp, used for syrups, jams and sim.

1b TS bot. com. Rutaceae bushy agrume (Citrus aurantium) with elliptical leaves and white flowers that produces this fruit

$2 \mathrm{CO}$ carbonated soft drink, bitter, flavored with extracts of this citrus

Treccani

chinòtto s. m. [dal nome della Cina (nella forma ant. China), ritenuta il luogo di provenienza]. - 1. Alberetto cespuglioso delle rutacee (Citrus aurantium var. myrtifolia), alto da 2 a $3 \mathrm{~m}$, coltivato in Liguria, nella Riviera francese, ecc.: è un agrume con foglie piccole, ellittiche, a picciolo debolmente alato, il cui frutto (detto anch'esso chinotto), rotondo, giallo aranciato, a polpa acida, viene adoperato per canditi o conservato in sciroppo. 2. Bibita analcolica, gassata, aromatizzata con estratto di chinotto.

Chinòtto [...] 1. Bush of rutaceae (Citrus aurantium var. Myrtifolia), 2 to $3 \mathrm{~m}$ tall, cultivated in Liguria, in the French Riviera, etc.: it is an agrume with small, elliptical leaves, with a slightly winged petiole, the fruit of which ( also called chinotto), round, orange-yellow, with acid pulp, it is used for candied fruit or preserved in syrup. 2. Soft drink, carbonated, flavored with chinotto extract.

Consequently, if one does not know that a limetta or a pomelo, for instance, are a kind of agrumi, it will be difficult for dictionary users to find out information. The only way of relating these terms to their superordinate is first to look for the lemma, and second to know what is meant under rutaceae.

Curiously, Zingarelli quotes examples of agrumi, which are defined only as rutaceae under the lemma frutta (fruit) and more precisely under fruit variety:

Varietà di frutta: [...] agrumi (arancia, clementina, mandarancio, limone, mandarino, pompelmo, mapo, cedro) [...].

Fruit variety [...] agrumi (orange, clementine, mandarin orange, lemon, mandarin, grapefruit, mapo, cedar) [...] 
The GDU and Treccani, being larger dictionaries, also enlist older varieties that are not produced anymore, at least in Italy, or relatively new hybrids such as the egle, the ugli/ugly, the eremocedro, or the Feronia, which are extremely difficult to translate as well, as no common bilingual dictionary has them in its word list, unlike other words which are untranslatable but still present in bilingual lexicopraphy (eg. chinotto, § 4).

The most accurate description of agrume as hyperonym to the rutaceae family trees and fruits is WordNet, where the taxonomy and the lexical relationship between superordinate and its species are clearly and systematically displayed. In Figure 3, we can recognize most of the lemmata listed in the three columns of Table 1, but the outline is even more refined and we can identify exotic varieties such as the satsuma and different varieties of oranges.

The approach in Wordnet is onomasiological and no history of the term is implied. In fact, one can clearly observe that the elsewhere homonymic entries agrume 1 and 2 here are not based on etymological or historical principles, but rather on the different fields of interest. The same words appear under both entries, but first with the label Gastronomy, because they designate a fruit which can be eaten or squeezed to make juice, and secondly with the label Biology, dealing with trees from which fruits come or that are used as grafting stock.

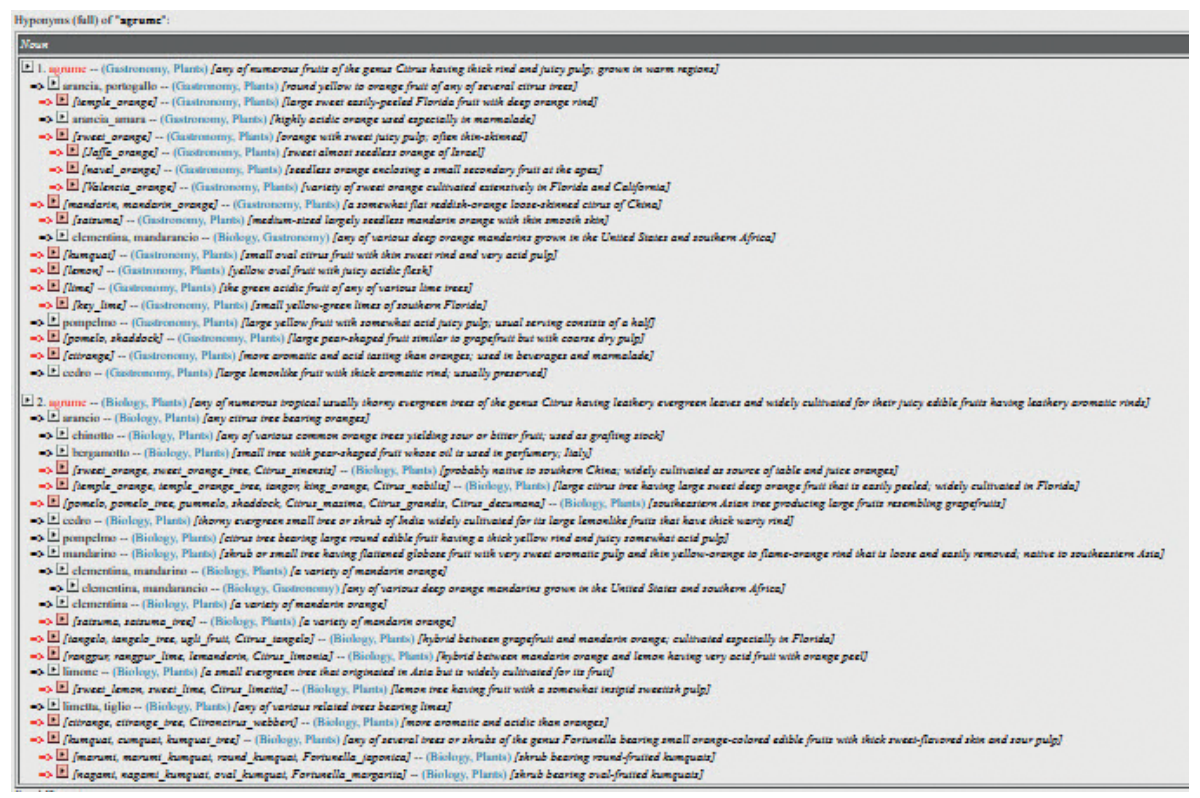

Figure 3: Agrume as hyperonym in WordNet 


\section{Squeezing bilingual dictionaries}

Bilingual dictionaries are by definition necessarily less extensive than monolinguals, thus their word lists might not be as thorough. Nonetheless, they are the source foreign learners turn to when they have to grasp language (i.e. lexical) facts, and therefore they also constitute bridges between cultures and - in this contexts - landscapes.

Squeezing bilingual dictionaries of the Zanichelli online suite for agrume/i, a first difference between the word lists of the languages involved comes out: the term in the Italian section of the dictionary is not linked at all with the fruits and trees it indicates.

The Ragazzini, for instance, mentions agrume in its articles just as an example of fruit (lemma) variety, an ingredient for jams under the entries confettura and marmellata, the meronym of spicchio (segment), and a bunch of derivatives (agrumeto, agrumicolo, agrumicoltore...). The results of the same query in the Italian $>$ French Boch, Italian>German Giacoma/Kolb, and Italian>Spanish Sañé/Schepisi return even fewer hits, i. e. derivatives only.

The results are better if we query the other sections of the dictionaries. Looking up citrus in the Ragazzini, quite a broad list of agrumi fruits and trees is generated and it comprises some unexpected words like bigarade. Using the English term, which happens to be the term used to identify the genus in Italian, allows users to trace citrus fruits and trees also in the Italian section: arancio, bergamotto, cedro (1), chinotto, limetta (2), mandarino (2), melangolo, melarancio, pomelo, pompelmo, satsuma, are all entries that one cannot find through agrum ${ }^{\star}$.

Still there is a certain inconsistency between the two definitions, as we can see from the comparison of pomelo, referred to as Citrus paradisi or Citrus maxima in English, but as Citrus grandis in Italian.

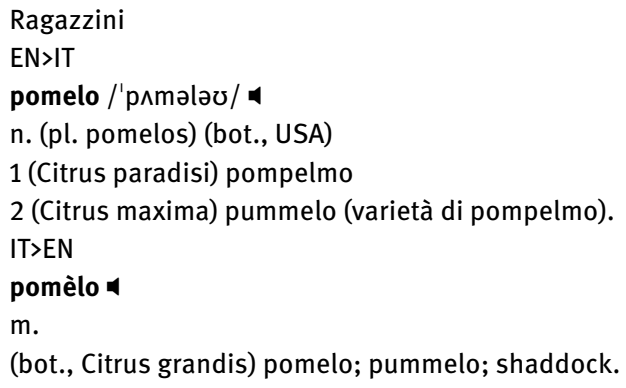

The Italian/English dictionary of the Zanichelli online suite seems to be the only one to agrume under a superordinate - citrus - which happens to be the English term used in the botanical taxonomy for the genus as well.

All the other bilingual dictionaries do not mention either the botanical family and genus of the fruits and trees or a CO/AD (following De Mauro's classification) word to identify them as part of a semantic group, they just give the equivalent. 
Bilingual dictionaries are particularly interesting to compare the possible translations of words that are untranslatable, because they belong to a specific national landscape.

The Chinotto tree (citrus myrtifolia), for instance, is a plant which is typical of the Liguria region (but grown also in Tuscany, Sicily, and Calabria), whose name probably comes from the place is was originally imported from: China. The fruits are used in the food industry to produce a drink named as the tree, which apparently is known exclusively in Italy.

In fact, the entry chinotto is listed only in the Italian section of the bilingual dictionaries examined, and with different contents.

Comparing Garzanti and Zingarelli, we can observe a similar structure of the article - 1 is for the botanic description, 2 is for the drink - and an analogous definition - the shape of the leaves and the classification as oranges; the botanic taxonomy, though, is different and thus confusing.

Garzanti

chinòtto

n.m.

1. (bot.) (Citrus aurantium myrtifolia) chinotto, myrtle-leaved orange

2. (bevanda) soft drink flavoured with chinotto.

Zingarelli

chinòtto 4

m.

1 (bot., Citrus bigaradia sinensis) myrtle-leaf sour orange; chinotto

2 (bibita) myrtle-leaf sour orange drink; chinotto.

Other bilingual dictionaries do not give account for the botanical taxonomy but, unlike the English sections, they give an equivalent of chinotto, making it apparently translatable into chinois, Bitterorange, quinoto.

One may assume that at least in French the fruit/tree and the drink is popular and is part of the landscape, since the species is grown in Côte d'Azur and the dictionary reports a French equivalent.

ilBoch

chinòtto 4

s. m.1 (frutto) chinois2 (bevanda) boisson à base de chinois.

A quick search on the FRTenTen corpus contradicts the Boch: Chinois merely refers to the population, while both the tree/fruit and the drink are simply quoted as Chinotto, or at most Chinoto (as in (5)). 
(5a) Cuisson des pois chiches au chinotto (Photo LOF - Chinoto ou chinotto : orange amère à feuilles de myrte)

[FRTenTen]

(5b) La production industrielle du soda de chinotto remonte aux années 1950. Le soda est produit en Italie par plusieurs compagnies et il est principalement consommé en Italie et à Malte.

[FRTenTen]

Similarly, the Giacoma/Kolb German and Italian dictionary translates the botanical term with an approximate compound word and the drink with a circumlocution which does not clarify the true nature of Chinotto.

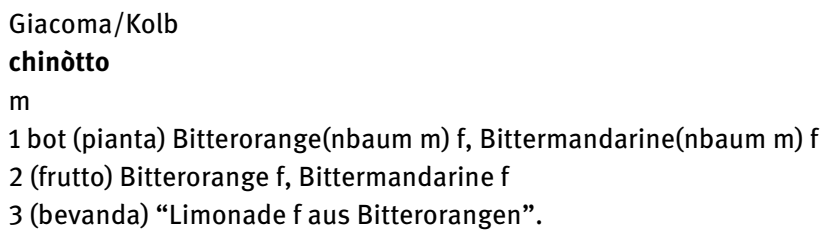

Moreover, other sources (cfr. DETenTen in (6a-b) and Wikipedia in (7)) still use the Italian word to refer to both meanings.

(6a) Erweitert wird die Palette durch Heidelbeere, Bitterorange, Grapefruit, Chinotto und Hausmischungen, die meist nur regional und/oder saisonal begrenzt erhältlich sind.

[DETenTEn]

(6b) Das Tonicwasser mit der bitteren Note von Chinotto ist an Trockenheit kaum zu überbieten. $</ s><s>$ Das macht es zu einer großartigen Basis von Mixgetränken.

[DETenTEn]

(7) In der Sortengruppe Chinotto werden einige Sorten der Bitterorange (Citrus $x$ aurantium, Syn. Citrus aurantium var. myrtifolia, Citrus myrtifolia) zusammengefasst. Der Saft wird in Italien vielen Digestifs zugesetzt und ist außerdem in Campari enthalten. Unter dem Namen Chinotto ist auch ein Erfrischungsgetränk auf dem Markt, das hauptsächlich aus dem Saft der Frucht hergestellt wird.

The only bilingual dictionary where the equivalent corresponds to the use in the actual language is Spanish, as proved in $(8 a-b)$.

(8a) No es lo mismo el kumquat (fortunella o citrus japonica) que el quinoto (también lo he visto escrito kinoto y chinotto , a la italiana) que es citrus myrtifolia.

[ESTenTen]

(8b) Con extractos de Quinoto de Savona. $\langle/ \mathrm{s}\rangle\langle\mathrm{s}\rangle$ El Quinoto contiene antioxidantes con propiedades anti-inflamatorias, entre los cuales está la vitamina $C$ 
Sañé/Schepisi

chinòtto

s. m.

(bot.) quinoto.

On the other hand, this dictionary diverges from the others providing only the botanical meaning ignoring the gastronomic use of the fruit.

Another interesting word to comment on is mandarancio, a hybrid of mandarin and orange from the botanical point of view, which in Italian is a synonym of clementina. Many Italian speakers, though, would consider the two terms as referring to two different fruits and many people do not know that they are the very same tree/fruit, as proved by the yahoo!answer - and question - below (9).

$(9)^{7}$ mi dite la differenza tra mandaranci e clementine? discussione accesa in casa mia!grazie:)

le clementine sono i mandarini senza i semi. I mandarini hanno i semi. I mandaranci sono un incrocio tra i mandarini e le arance, quindi sono dei mandarini più grandi, hanno una buccia un po più spessa e possono essere sia con i semi che senza

mandaranci sn anke piu grandi e hanno i semi...i clementini piu dolci e senza semi=)

O_o Discussione accesa a tavola per un frutto??? ahahah cmq secondo me il mandarancio è un incrocio tra arancia e mandarino normale i clemetini sono i mandarini dolci senza noccioli...boo!!

Monolingual dictionaries describe both terms as a cross between bitter or sweet oranges and mandarins, some do mention the synonymic relation, some others don't, hence the general confusion in the public. Curiously, the bilinguals of the Zanichelli suite only return clementine as equivalent in any of the languages considered, so there is a lack in the formal correspondences between the Italian twofold signifiers and the foreign translation, where mandarancio - which is the older word (1950 according to De Mauro vs 1963 for clementina) - has no matching form. The sections foreign language > Italian, though, offer both equivalents from English, French, and German, but only clementina from Spanish.

7 can you tell me the difference between mandaranci and clementine? heated discussion in my house! thanks :)

clementines are mandarins without seeds. Mandarins have seeds. Mandaranci are a cross between mandarins and oranges, so they are larger mandarins, have a slightly thicker skin and can be either with or without seeds.

mandaranci are also larger and have seeds ... the sweetest and seedless clementine $=$ )

O_o Heaten discussion at the table for a fruit ??? hahaha btw I think the mandarancio is a cross between orange and mandarin normal clemetini are sweet mandarins without seeds ... boo !! 


\section{Squeezing other reference sources}

Within the agrumi category, oranges are certainly the most popular, and as prototypes of the group the relationship hyponym-hyperonym often emerges in general discourse. Querying the NUNC corpus, a suit of corpora based on newsgroups (Barbera et al. 2007), demonstrates that the folk taxonomy outlined in the users' posts is the one we expected to find in dictionaries at the beginning of this research.

In (10) and (11) both the word agrumi and arancia (in its variants aranci, arancio, arance) are present in the same sentence and the latter exemplifies the former

(10) El cemeterio di mio paese produce molti morti e molti agrumi, come aranci, limoni e cococcielli. ${ }^{8}$

(11) La puzza sarà sicuramente minore, da quel che so ai gatti non piacciono gli agrumi, quindi potrebbe provare a seminare un po' di bucce d' arancio e odiano la stagnola ...9

And the same relation is used for the pun in (11)

(12) Come fanno la cacca le arance? A ... grumi! ${ }^{10}$

Other occurrences expand the scope of the superordinate to more cultivars: lemons, tangerines, yellow and pink grapefruits, cedars, clementines...

(13) E non solo i gerani, anche tutti gli agrumi, limoni, cedri, mandarini cinesi, pompelmi gialli e rosa ecc. A settembre ho seminato pompelmi rosa circa semi e sono nate piantine. ${ }^{11}$

(14) Farina kg - zucchero gr - bucce di agrumi grattugiate (mandarini, arancia, limone) nocciole e mandorle gr - acqua gr - cannella cucchiaio raso ${ }^{12}$

(15) Sembra incredibile, ma possibile. Avere agrumeti al Nord Veneto. Pompelmi rosa/gialli, clementini, mandarini, arencie, cedri, limoni, (Eucalipti),

8 (9) El cemeterio of my village produces many deads and many agrumi, such as oranges, lemons and cococcielli

9 (10) The smell will surely be lighter, from what I know cats do not like agrumi, so they could try to sow a little orange peel and they hate tinfoil ...

10 How do oranges poop? A ... grumi (In... lumps)

11 And not only the geraniums, also all the agrumi, lemons, cedars, Chinese mandarins, yellow and pink grapefruits etc. In September I sowed pink grapefruit seeds and seedlings were born.

12 Flour kg - sugar gr - grated agrumi peels (tangerines, orange, lemon) hazelnuts and almonds gr - water gr - full cinnamon spoon 
mandaranci, mandarini cinesi e mandarini Israeliani in coltivazioni naturali. Svernano all'aperto senza alcuna protezione al Nord. ${ }^{13}$

(15) is also a good example to show how the definition of a category is closely connected to the landscape, as we find out that many agrumi are successfully grown in the North of Italy (Veneto) and not only in the South. Here the writer uses the derivative agrumeto (citrus orchard) and afterwards specifies the different species that are meant by the umbrella term, thus proving its collective nature.

This also occurs in the following examples, where the agrumi emerge as typical Mediterranean crops (Calabria and Sicily are mentioned).

(17) Dal poggio si domina l'intera piana di Catania con i suoi agrumeti e i campi di grano. $^{14}$

(18) sono state create le famose cattedrali nel deserto nel meridione d'Italia tipo “GIOIA TAURO” distruggendo piantagioni di agrumi e rovinando località ${ }^{15}$

(19) Di particolare interesse sono il mercato del pesce di Corigliano, uno dei più importanti della Calabria, il mercato degli agrumi e le attività collegate all'edilizia ed alle costruzioni, con il conseguente controllo dei materiali necessari $^{16}$

As already noticed for Blumenthal Rovere quotations in $\S 3$, from the NUNC contexts the textual genre-related use of the word agrume - i.e. articles, descriptions, academic texts, compared to the references to arancia, mandarino and other sorts of citrus, is clear. It is a feature common to all superordinate words, but it is striking if you think of the stereotypical Italian character of such fruits and the common understanding of the term by Italian speakers.

13 It seems incredible, but possible. Having agrumeti (citrus orchards) in Northern Veneto. Pink / yellow grapefruits, clementines, mandarins, oranges (sic), cedars, lemons, (Eucalyptus), clementines, Chinese mandarins and Israeli mandarins in natural crops. They winter in the open without any protection in the North.

14 From the hillock you dominate the entire plain of Catania with its agrumeti (citrus orchards) and wheat fields

15 the famous cathedrals in the desert in the south of Italy have been created like "GIOIA TAURO", destroying piantagioni di agrumi (citrus plantations) and ruining locality

16 Of particular interest are the fish market in Corigliano, one of the most important in Calabria, the agrumi market and activities related to building and construction, with the consequent control of the materials needed 


\section{Conclusions}

Monolingual and bilingual dictionaries are not always the most useful sources to address in order to sketch the landscape of a country through its language. As we have demonstrated in this case study on agrume, the categorization of the hyponyms and the members of the taxonomy largely depends upon the choices of each dictionary, which are not always consistent. A full text searches might not give the expected results and one has to look up the single entry to link the cultivar to its genus and common superordinate.

In order to give a better lexicographic account of the landscape, dictionaries might want to consider to quote the hyperonym agrume in all the dictionary articles that are related to the category in order to have a proper mapping of its members.

As it has already been proved in other works on landscape and lexicography (Villalva/Williams 2019), a certain confusion in both monolingual and bilingual dictionaries can be observed. Especially in bilinguals, equivalents are not completely accurate and the treatment of some national products is inconsistent and blurred.

In the current trend of the enhancement of the typical products of a territory and the defense of the designation of origin, it would be appropriate that the dictionaries also contributed to better convey the peculiarities of a product through definitions that really help to identify the genus proximum and the difference among citruses, and consequently more precise translations.

\section{Bibliography}

\subsection{Research literature}

Barbera, Giovanni/Biasi Rita (2013): Paesaggio. In: Tribulato, Eugenio/Inglese, Paolo (eds.): Gli agrumi. Script-edizioni, 130-145 [https://www.colturaecultura.it/agrumi, last access: 20 December 2019].

Barbera, Manuel/Corino, Elisa/Onesti Cristina (2007) (eds.): Corpora e linguistica in rete. Perugia: Guerra.

Nicolosi, Elisabetta (2013): Inquadramento tassonomico. In: Tribulato, Eugenio/Inglese, Paolo (eds.): Gli agrumi. Script-edizioni, 2-15 [https://www.colturaecultura.it/agrumi, last access: 20 December 2019].

Villalva, Alina (2018): Heritage dictionaries, historical corpora and other sources. Essential and negligible information. In: Čibej, Jaka/Gorjanc, Vojko/Kosem, Iztok/Krek, Simon (eds.): Proceedings of the XVIII EURALEX International Congress: Lexicography in Global Contexts. Ljubljana: Ljubljana University Press, Faculty of Arts, 467-479.

Villalva, Alina/Williams, Goeffrey (2019) (eds.): The Landscape of Lexicography. Lisbon: Centro de Linguística da Universidade de Lisboa. 


\subsection{Dictionaries}

Blumenthal Rovere= Blumenthal, P./Rovere, G. (2019): Wörterbuch der italienischen Verben Dizionario dei verbi italiani, 3rd digital edition. Nürnberg: Acolada.

Devoto Oli = Devoto, G./Oli, G. C./Serianni, L./Trifone, M. (2017) (eds.): Nuovo Devoto-Oli. Il vocabolario dell'italiano contemporaneo. Firenze: Le Monnier.

Garzanti $=$ Garzanti on line. Dizionario Italiano Novara: DeAgostini/Garzanti linguistica [http://www. garzantilinguistica.it/, last access: 20 December 2019].

GDLI = Battaglia S./Barberi Squarotti, G. (1961-2002) (eds.): Grande dizionario della lingua italiana. Torino: UTET. Appendices 2004 and 2009; Index of Quoted Authors 2004 (GDLI).

GDU = De Mauro, T. $\left(1999,2007^{2}\right)$ (ed.): Grande dizionario italiano dell'uso, ideato e diretto da Tullio De Mauro, con la collaborazione di G. C. Lepschy and E. Sanguineti. 6 voll. Torino: UTET. Supplements: Nuove parole italiane dell'uso, 2003; Nuove parole italiane dell'uso 2, 2007. Torino: UTET (GDU).

Giacoma Kolb = Giacoma, L./Kolb, S. (2019): Il nuovo dizionario di Tedesco. Bologna: Zanichelli Klett Pons.

Il Boch = Boch, R. (2014): il Boch. Bologna: Zanichelli.

Il Nuovo De Mauro = De Mauro, T. $(2000,2016)$ (ed.): /l Nuovo De Mauro. [https://dizionario. internazionale.it/, last access: 20 December 2019].

Ragazzini = Ragazzini, G. (2019): /l Ragazzini 2020. Bologna: Zanichelli.

Sañé/Schepisi= Sañé, S./Schepisi, G. (2005): /l dizionario di spagnolo. Bologna: Zanichelli.

Tommaseo Bellini = Tommaseo N./Bellini, B. (1865-1879): Dizionario della lingua italiana. 4 voll. Torino: Unione Tipografico-Editrice Torinese [http://www.tommaseobellini.it/\#/ (Tommaseo-Bellini), last access: 20 December 2019].

Treccani = Della Valle, V./Patota, G. (2018) (eds.): /l nuovo Treccani \#leparolevalgono. Roma: Istituto della Enciclopedia italiana (Il nuovo Treccani).

Zingarelli = Cannella, M. /Lazzarini, B. (2019) (eds.): Lo Zingarelli 2020. Vocabolario della lingua italiana. Bologna: Zanichelli (Zingarelli 2019). 